\title{
NGNP: High Temperature Gas-cooled Reactor Key Definitions, Plant Capabilities, and Assumptions
}

May 2013

The INL is a

U.S. Department of Energy

National Laboratory

operated by

Battelle Energy Alliance

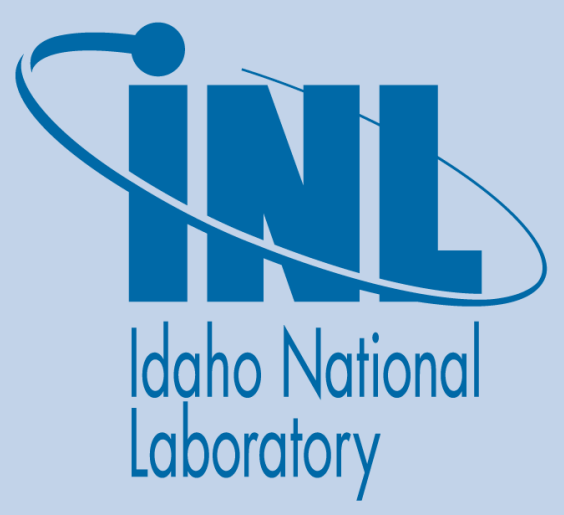

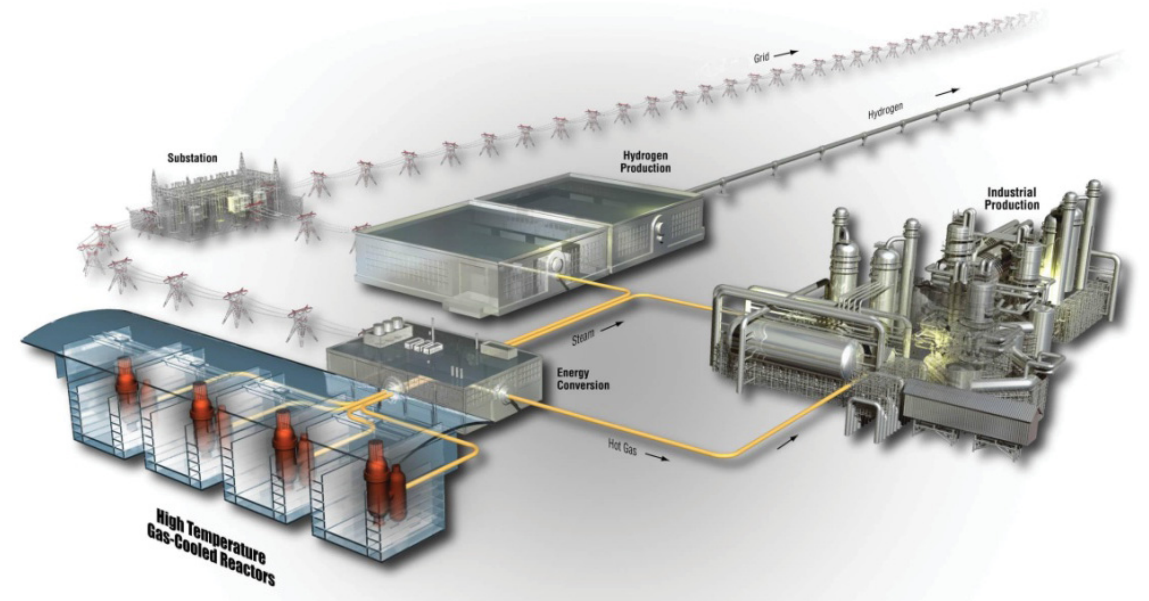




\section{DISCLAIMER}

This information was prepared as an account of work sponsored by an agency of the U.S. Government. Neither the U.S. Government nor any agency thereof, nor any of their employees, makes any warranty, expressed or implied, or assumes any legal liability or responsibility for the accuracy, completeness, or usefulness, of any information, apparatus, product, or process disclosed, or represents that its use would not infringe privately owned rights. References herein to any specific commercial product, process, or service by trade name, trade mark, manufacturer, or otherwise, does not necessarily constitute or imply its endorsement, recommendation, or favoring by the U.S. Government or any agency thereof. The views and opinions of authors expressed herein do not necessarily state or reflect those of the U.S. Government or any agency thereof. 


\title{
NGNP: High Temperature Gas-cooled Reactor Key Definitions, Plant Capabilities, and Assumptions
}

May 2013

\author{
Idaho National Laboratory \\ Next Generation Nuclear Plant Project \\ Idaho Falls, Idaho 83415
}

http://www.inl.gov

Prepared for the

U.S. Department of Energy

Office of Nuclear Energy

Under DOE Idaho Operations Office

Contract DE-AC07-05ID14517 

Next Generation Nuclear Plant Project

\section{NGNP: High Temperature Gas-cooled Reactor Key Definitions, Plant Capabilities, and Assumptions}

\section{INL/EXT-11-23797}

Revision 1

May 2013

Approved by:
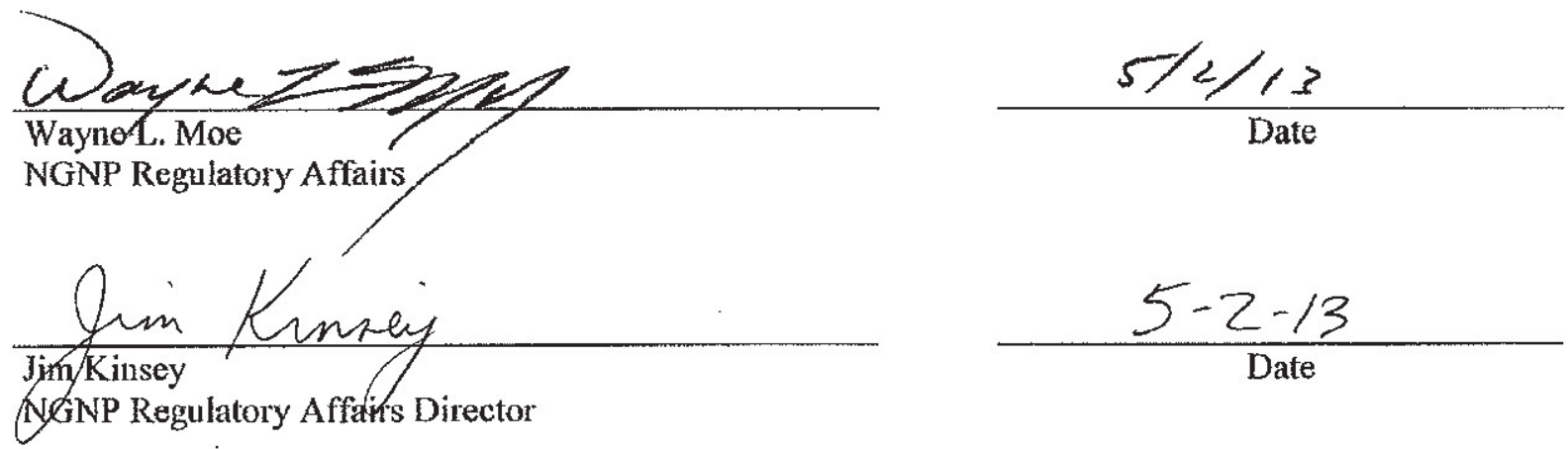


\begin{abstract}
This document provides key definitions, plant capabilities, and inputs and assumptions related to the Next Generation Nuclear Plant (NGNP) to be used in ongoing efforts related to the licensing and deployment of a high-temperature gas-cooled reactor. These definitions, capabilities, and assumptions were extracted from a number of NGNP sources such as licensing related white papers, previously issued requirement documents, and preapplication interactions with the Nuclear Regulatory Commission.
\end{abstract}




\section{CONTENTS}

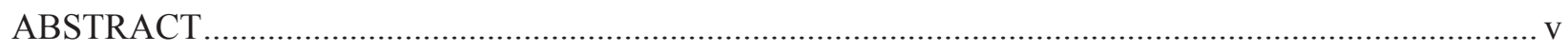

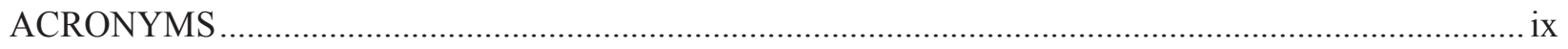

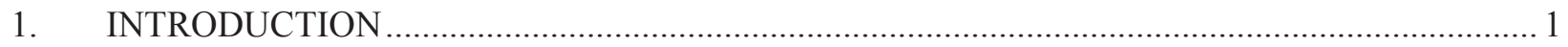

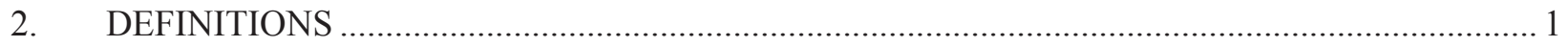

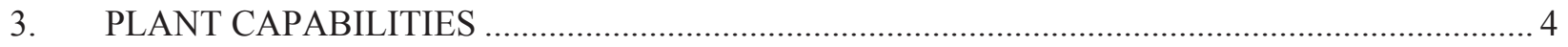

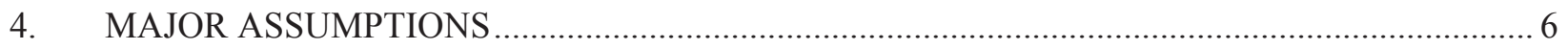

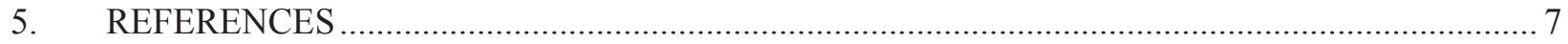

\section{TABLE}

Table 1. Event selection comparison - site suitability vs. emergency planning. ..................................... 7 


\section{ACRONYMS}

$\begin{array}{ll}\text { AE } & \text { Anticipated Event } \\ \text { BDBE } & \text { Beyond Design Basis Event } \\ \text { DBA } & \text { Design Basis Accident } \\ \text { DBE } & \text { Design Basis Event } \\ \text { EAB } & \text { exclusion area boundary } \\ \text { EP } & \text { Emergency Planning } \\ \text { EPZ } & \text { Emergency Planning Zone } \\ \text { EPA } & \text { Environmental Protection Agency } \\ \text { F-C } & \text { Frequency-Consequence } \\ \text { FOAK } & \text { first-of-a-kind } \\ \text { HTGR } & \text { high temperature gas-cooled reactor } \\ \text { LBE } & \text { Licensing Basis Event } \\ \text { NHSS } & \text { nuclear heat supply system } \\ \text { NOAK } & \text { Nth-of-a-kind } \\ \text { NRC } & \text { Nuclear Regulatory Commission } \\ \text { NGNP } & \text { Next Generation Nuclear Plant } \\ \text { PAG } & \text { protective action guides } \\ \text { PRA } & \text { probabilistic risk assessment } \\ \text { SSC } & \text { structures, systems, and components } \\ \text { SST } & \text { Siting Source Term } \\ \text { TLRC } & \text { Top Level Regulatory Criteria } \\ \text { TRISO } & \text { tristructural-isotropic } \\ & \end{array}$




\section{NGNP: High Temperature Gas-cooled Reactor Key Definitions, Plant Capabilities, and Assumptions}

\section{INTRODUCTION}

This document provides a Next Generation Nuclear Plant (NGNP) tool to collect and identify key definitions, plant capabilities, and inputs and assumptions to be used in ongoing efforts related to the licensing and deployment of a high-temperature gas-cooled reactor (HTGR). These definitions, capabilities, and assumptions are extracted from a number of sources, including NGNP documents such as licensing related white papers (References 1-11), previously issued requirement documents (References 13-15), and ongoing preapplication interactions with the Nuclear Regulatory Commission (NRC) (References 19-20). Additions or changes to this document will be as agreed upon by the NGNP Regulatory Affairs group's Licensing Working Group. The NGNP's approach to licensing an HTGR plant is defined within the referenced white papers and in DOE's 2008 report (Reference 12), and is not duplicated here.

The information herein applies to an HTGR-based nuclear heat supply system (NHSS) comprised of either a prismatic or pebble bed reactor concept, a graphite core, helium primary coolant, and necessary support systems and heat transport system interfaces with an energy conversion system and energy transfer systems. The energy demand can include the regional electric grid, which is supplied electricity; an industrial process requiring electricity and heat via steam or other high-temperature fluid; a hydrogen production facility; special applications such as recovery of hydrocarbons from oil sands and oil shale; or a combination of these.

This document places an initial set of information related to key definitions, plant capabilities, and inputs and assumptions under configuration management. The body of information will be updated and expanded on as licensing and design efforts mature via controlled revisions to this document.

\section{DEFINITIONS}

This section is meant to capture useful definitions that specifically apply to discussions related to the licensing and deployment of an HTGR that are not necessarily found in other common source material such as the NRC glossary, sets of definitions provided in national codes and standards, or NRC policy statements. This is not an attempt to duplicate all definitions already found in those source materials. The definitions related to modular plant configurations are consistent with those used by NGNP in documentation related to commercial deployment of an HTGR.

These definitions may be revised and/or added to as additional definitions are developed.

Anticipated Event (AE). Licensing Basis Events (LBEs) that are those conditions of plant operation expected to occur one or more times during the life of the plant. Event sequences from the Probabilistic Risk Assessment (PRA) are classified as AEs when their expected frequencies of occurrence are greater than $1 \times 10^{-2}$ per plant-year. (Source: NGNP Regulatory Affairs Configuration Council, July 26, 2011, as amended by NGNP Issue Resolution Worksheet2.a.-4, October 11, 2012.)

Barrier. A feature that provides resistance to the transport and release of one or more fission product radionuclide species. (Source: NGNP Regulatory Affairs Configuration Council, July 26, 2011.)

Beyond Design Basis Event (BDBE). LBEs that are not expected to occur during the lifetime of a large fleet of nuclear power plants, but are considered to assure that the risk to the public from low frequency events is acceptable. As used within this definition, event sequences from the PRA are classified as BDBEs when their expected frequency of occurrence is between $5 \times 10^{-7}(5 \mathrm{E}-07)$ and $1 \times 10^{-4}(1 \mathrm{E}-04)$ per plant year. (Source: NGNP Regulatory Affairs Configuration Council, July 26, 2011.) 
Bounding event sequence (BES). An event sequence based on a deterministic review of credible events that are evaluated to ensure that there are no cliff edge effects, account for plant-specific uncertainties, and to establish a bounding set of hazards that will not be exceeded by other accidents considered credible. (Source: RAI FQ/MST-19 response, NGNP presentations to the NRC during public meetings April 12, 2012, September 20, 2012, and November 14, 2012.)

Defective fuel particle. A tristructural-isotropic (TRISO) coated fuel particle where the as-manufactured condition has missing or defective buffer, $\mathrm{IPyC}, \mathrm{SiC}$, or OPyC coating layers. (Source: NGNP Issue Resolution Worksheets 1.a and 3.c, RAI MST-115 response, April 17, 2012 NGNP-NRC public meeting information.)

Design Basis Accident (DBA). LBEs that are postulated accidents for which a nuclear facility must be designed and built to withstand without loss to the structures, systems, and components (SSCs) necessary to ensure public health and safety. HTGR DBAs are analyzed in Chapter 15 of the Safety Analysis Report. DBAs are analyzed by assuming that only SSCs classified as safety-related are available to mitigate the consequences of the accident. (Source: NGNP Regulatory Affairs Configuration Council, July 26, 2011.)

Design basis event (DBE). DBEs are LBEs that are not expected to occur during the lifetime of a single nuclear power plant, but they may be encountered during the lifetime of a population of nuclear power plants of similar design. Event sequences from the PRA are classified as DBEs when their expected frequencies of occurrence are less than $1 \times 10^{-2}$ per plant-year and greater than $1 \times 10^{-4}$ per plant-year. (Source: NGNP Regulatory Affairs Configuration Council, July 26, 2011.)

Designer. The entity that performs the design of the HTGR energy supply and supports the licensing activities by the operator. (Source: INL/EXT-10-19887, Section 4.)

End user. The entity whose facility is being supplied the required energy in the forms specified and on whose property the HTGR energy supply is located. (Source: INL/EXT-10-19887, Section 4.)

Failed fuel particle. The degradation of fuel particle coating, which occurs to the point that there is a pathway from the kernel to the outer surface of the particle. (Failed fuel particles still provide a significant radionuclide retention capability). (Source: NGNP Regulatory Affairs Configuration Council, July 26, 2011.)

First-of-a-kind (FOAK). May refer to either a module or a plant. The FOAK module will provide the basis for licensing of a particular HTGR-NHSS unit design. The FOAK plant may not have all modules constructed simultaneously and thus may contain modules that are either identical or that have some progression of component or configuration development. (Source: Generic usage, formally established herein.)

Functional containment. The multiple barriers to fission product release and radionuclide transport that limit the release of radionuclides to the environment. This functional containment is comprised of the kernel and coatings of the TRISO coated fuel particles, fuel matrix and fuel element graphite, helium pressure boundary, and reactor building. Each of these barriers contributes to limiting the release of radionuclides to the environment to meet the NGNP Project Top Level Regulatory Criteria (TLRC). The contribution of each of the barriers in limiting the transport and release of radionuclides to the environment is calculated for each postulated event, depending on the response of the module to the event. (Source: NGNP Regulatory Affairs Configuration Council, July 26, 2011.)

Functionally degraded fuel particle. Functional degradation of coated fuel particles refers to those circumstances under which fuel particle coating degradation occurs to the point that the radionuclide retention capabilities of the particle are reduced relative to an intact TRISO fuel particle. (Source: NGNP Regulatory Affairs Configuration Council, July 26, 2011.) 
Intact fuel particle. Fuel particles in which TRISO coatings remain structurally intact. It is recognized that the diffusion/release of some metallic fission products occurs from intact fuel particles (e.g., at rates associated with the fuel's time at temperature). (Source: NGNP Regulatory Affairs Configuration Council, July 26, 2011.)

Licensing basis events (LBES). The events derived from the HTGR technology and plant design that are considered by the licensing process and are used in the development of the license application. LBEs include AEs, DBEs, DBAs, and BDBEs. (Source: NGNP Regulatory Affairs Configuration Council, July 26, 2011.)

Mechanistic source terms. The event-specific mechanistic approach taken in developing radiological source terms for LBEs includes the quantities, timing, physical and chemical forms, and thermal energy of radionuclides released from the reactor building to the environment. (Source: NGNP Regulatory Affairs Configuration Council, July 26, 2011.)

Module. An individual HTGR-NHSS unit. If the configuration includes a dedicated Energy Conversion System, the module may consist of the HTGR-NHSS and Energy Conversion System. (Source: Generic usage, formally established herein.)

Nth-of-a-Kind (NOAK). NOAK refers to a mature and standardized configuration of a module or a plant. The NOAK module or plant is one where the design, licensing process, and capital costs are well established. (Source: Generic usage, formally established herein.)

Nuclear heat supply system (NHSS). The NHSS includes the nuclear island (e.g., the reactor, primary coolant system, and supporting systems) and the heat transfer/transport system of each HTGR module. (Source: INL/EXT-10-19887, Section 1.)

Operator. The entity that is licensed to operate the HTGR energy supply. (Source: INL/EXT-10-19887, Section 4.)

Owner controlled area. The area surrounding and including the modular HTGR plant governed by the operator's normal operating procedures. This area will likely defined by a fence at the site's boundaries that is controlled by the plant's security forces. (Source: Generic usage, formally established herein.)

Passive cooling path. The cooling path designed and relied on in the safety analysis for achieving a safe stable state condition is the reactor cavity cooling system rejecting heat to the ultimate heat sink. The ultimate heat sink is nominally the atmosphere surrounding the HTGR module. (Source: NGNP Regulatory Affairs Configuration Council, July 26, 2011.)

Plant. The overall configuration of one or more HTGR-NHSS modules with associated energy conversion and balance-of-plant systems (i.e., "a collection of reactor modules having selected shared systems"). (Source: Generic usage, formally established herein and NGNP Issue Resolution Worksheet 2.a-3, October 11, 2012.)

Safe stable state. A plant state in which plant conditions are maintained at or near established values and within the success criteria for maintenance of safety and design bases. (Safe stable states correspond with successful plant response end states in the PRA modeling of event sequences.) (Source: NGNP Regulatory Affairs Configuration Council, July 26, 2011.)

Siting source term. The limiting mechanistic source term for licensing basis events that will be analyzed against the Top Level Regulatory Criteria during site suitability assessments. (Source: NGNP presentations to the NRC during public meetings September 20, 2012 and November 14, 2012.) 
Special treatment. Special treatment requirements help ensure that the frequencies and consequences of the LBEs fall within the TLRC as well as reduce the uncertainties about SSC reliability and performance in the context of the safety functions they perform in preventing and mitigating LBEs. The purpose of special treatment is to increase the level of assurance that the SSCs will perform as predicted under expected LBE conditions with the assessed uncertainties. (Source: NGNP Regulatory Affairs Configuration Council, July 26, 2011.)

\section{PLANT CAPABILITIES}

The plant capabilities described in this section provide an initial set of high-level design inputs associated with an HTGR concept and configuration such that the HTGR-NHSS is based on either a prismatic or pebble bed reactor concept using helium as the primary heat transport medium, TRISOcoated particle fuel, a graphite core, and metallic reactor pressure vessel with dimensions and operating plant conditions that support a safety basis that does not primarily rely on active safety-related systems to maintain the reactor fuel within limits under normal, abnormal, and accident conditions. The HTGR-NHSS primary helium circuit shall be physically separated from steam or high-temperature gas supplied to the process by a primary heat exchanger consisting of either an intermediate heat exchanger or steam generator.

The initial set of high-level design inputs for the HTGR plant concept shall:

1. Achieve NRC siting criteria and Environmental Protection Agency (EPA) Protective Action Guides (PAGs) that will protect the health and safety of the public and the environment such that under no postulated accident condition would public evacuation or sheltering be required. To achieve this objective, the NGNP must meet the:

- NRC siting criteria for both the plant exclusion area boundary (EAB) and low population zone (10 CFR 52.47/50.34) at a nominal distance of $400 \mathrm{~m}$ from the reactor centerline

- $\quad$ Early phase EPA plume exposure PAGs at the plant EAB.

This objective will also protect the food and water supplies from being unacceptably impacted by radionuclide contamination by either meeting the intermediate phase EPA ingestion pathway PAGs at the plant $\mathrm{EAB}$, or by assuring, through the specific siting analyses and related administrative controls, that no food or water supplies exist in the area immediately surrounding the EAB. (Source: Generic NGNP Project Objectives. See: [1] NGNP Regulatory Affairs Configuration Council, July 26, 2011, [2] INL-EXT-11-22708, Section 3; and [3] INL/EXT-11-24034, Section 1)

2. Limit event contamination levels of collocated facilities associated with postulated events such that industrial facilities can be returned to operation with efforts acceptable to the licensee and the industrial plant(s) owners. This will be addressed (in part) through use of a frequency/consequence curve for investment protection. (Source: NGNP Regulatory Affairs Configuration Council, July 26, 2011.)

3. Interface with energy conversion systems such that the HTGR-NHSS design is capable of interfacing with multiple potential energy conversion configurations such as:

- Electricity supplied to the regional grid and/or to support process operations

- Steam to supply steam turbine generators or for general use throughout the facility

- Process heat in the form of high-temperature fluid to offset the emissions of greenhouse gases (e.g., attendant to the burning of natural gas and waste gases in industrial processes).

Not all applications will require the supply of all of these forms of energy, but the fundamental plant design shall be capable of providing any mix of these forms as required by each specific application. (Source: INL/EXT-10-19887, Section 3.3.) 
4. Support multiple module configurations. The HTGR-NHSS shall be designed as a standalone module that is capable of being combined with other modules in a multiple module configuration with varying module configurations to meet energy demand requirements that exceed the rating of an individual module. (Source: INL/EXT-10-19887, Section 3.4.)

5. Limit normal maintenance exposure to no more than 50 person-REM/year per module. (Source: INL/EXT-10-19887, Section 3.7.)

6. Achieve performance capabilities for normal and emergency demand transients such that when operating at power, the HTGR Plant is capable of responding to the following process transients without interruption or degradation of supply:

- $\quad$ Steam Headers

- $\quad$ Step Change: $\pm 10 \%$

- Maximum rate of change: $20 \% /$ min decreasing

- Maximum rate of change: $20 \% /$ min increasing

- Electric Power

- $\quad$ Step Change: $\pm 10 \%$

- Maximum rate of change: $10 \mathrm{MWe} / \mathrm{min}$ decreasing

- Maximum rate of change: $10 \mathrm{MWe} / \mathrm{min}$ increasing

- High-Temperature Fluid

- $\quad$ Step Change: $\pm 10 \%$

- Maximum rate of change: $20 \% /$ min decreasing

- Maximum rate of change: $20 \% / \mathrm{min}$ increasing.

7. The Plant shall be capable of accepting a full-load rejection from either steam, electrical, or hightemperature gas demand. (Source: INL/EXT-10-19887, Section 4.7.)

8. Achieve availability requirements supporting commercial process heat usage. The average required supply of steam to the steam headers, high-temperature gas to the gas headers, and electrical power generation to the electrical interconnections shall be available $100 \%$ of the time ( 24 hours a day, 7 days a week, 365 [366 in leap years] days per year). The $\mathrm{N}-\mathrm{x}^{\mathrm{a}}$ availability requirements for the plant will vary according to the specific application. The most stringent identified to-date requires meeting the availability requirements with two of the nuclear heat supply modules out of service. (Source: INL/EXT-10-19887, Section 4.8.)

9. Accomplish passive residual heat removal to the environment in a way that maintains fuel temperatures and core and plant structures, including concrete, within acceptable limits when neither the primary helium circulator nor the shutdown cooling system is available under normal, abnormal, and accident conditions (the nuclear system safety basis shall not depend on active cooling systems during DBA conditions). (Source: INL/EXT-10-19887, Section 5.5.)

10. Provide reactor outlet temperatures capable of supporting process heat usage. The HTGR-NHSS reactor gas outlet temperature shall be in the range of 750 to $950^{\circ} \mathrm{C}$. The HTGR-NHSS shall be designed for operation at the highest temperature achievable for the reactor core design (pebble bed, the prismatic cores) and to satisfy required safety margins. (Source: INL/EXT-10-19887, Section 6.1.)

a $\mathrm{N}$ is the number of HTGR-NHSS modules in the plant, $\mathrm{x}$ is the number that could be out of service for which the availability requirements must be met 


\section{MAJOR ASSUMPTIONS}

The major assumptions regarding meeting the plant capabilities discussed in Section 3 are as follows:

1. Exclusion Area Boundary. For design purposes, the EAB is established as approximately 400 meters from the reactor centerline. (Source: INL/EXT-10-19887, Section 3.6.) (Source: NGNP Regulatory Affairs Configuration Council, July 26, 2011.)

2. Event Response. The use of all available systems and associated operator actions can be assumed when evaluating the HTGR response to events other than DBAs, to satisfy the TLRC. (Source: NGNP Regulatory Affairs Configuration Council, July 26, 2011.)

3. Uncertainty. Uncertainty, when used in event evaluations, is applied as follows:

- All AEs, DBEs, and BDBEs have an uncertainty distribution on both their frequency and consequence evaluations.

- $\quad$ On the TLRC Frequency Consequence (F-C) chart, the lower bound (5\%), mean, and upper bound $(95 \%)$ uncertainty distributions of each $\mathrm{AE}, \mathrm{DBE}$, and BDBE are displayed.

- The mean value of the AE consequences is compared to the dose limit shown in the F-C chart based on 10 CFR 20 at the EAB.

- The 95\% upper bound of DBE consequences is compared to the dose limit shown in the F-C chart based on 10 CFR 50.34 at the EAB.

- The $95 \%$ upper bound of the deterministic DBA consequences is compared to the 10 CFR 50.34 limit at the EAB.

- The mean value of the DBEs and BDBEs is compared to the PAG limit shown in the F-C chart at the EAB.

- The cumulative mean value of all AEs, DBEs, and BDBEs is compared to the Qualitative Health Objective risk limits at the specified distances. (Source: NGNP Regulatory Affairs Configuration Council, July 26, 2011.)

- The frequencies of LBEs are expressed in units of events per plant-year, where a plant is defined as a collection of reactor modules having selected shared systems. (Source: NGNP Issue Resolution Worksheet 2.a.-3, October 11, 2012.)

- The guidelines for the upper and lower frequency bounds for categorizing events on the F-C chart shall be on a per plant-year basis. (Source: NGNP Issue Resolution Worksheet 2.a.-3, October 11, 2012.)

- The mean frequency is used to determine whether the event sequence family is an AE, DBE, or BDBE. If the upper or lower bound on the LBE frequency straddles two or more regions, the LBE will be analyzed following the methodologies and acceptance criteria of each region. (Source: NGNP Issue Resolution Worksheets 2.a.-2 and 2.a-6, October 11, 2012.)

- The application of mean versus upper bounded uncertainty when evaluating siting source terms as compared to emergency planning is summarized in Table 1 below. (Source: NGNP presentation to the NRC during a public meeting to address emergency planning on November 14, 2012.)

4. Dispersion Factors. The atmospheric dispersion factors provided in Reference 16 shall be used when performing dose estimating analyses at the site boundary and beyond. (Source: INL/EXT-11-24034.)

5. HTGR-NHSS Lifetime. The HTGR-NHSS shall have a plant design lifetime of 60 years (calendar). This corresponds to 500,000 hours of operation for construction code compliance. (Source:

INL/EXT-10-19887, Section 5.1) 
6. Construction Rules for Nuclear Facility Components. The HTGR-NHSS shall be designed to the construction rules of ASME Boiler and Pressure Vessel Code (Reference 17). (Source: Generic assumption formally established herein.)

7. Reference Nuclear Fuel. The HTGR reference fuel shall be TRISO coated particle fuel, LEU-based ( $\mathrm{UCO}$ or $\mathrm{UO}_{2}$ ) with an enrichment limited to $<20.0 \%$ (in mass) and with a peak burnup limited to $20 \%$ fissions per initial metal ion. (Source: INL/EXT-10-19887, Section 5.2.)

Table 1. Event selection comparison - site suitability vs. emergency planning.

\begin{tabular}{|c|c|c|c|c|c|}
\hline \multirow{2}{*}{$\begin{array}{l}\text { Event } \\
\text { Categoryl } \\
\text { Type }\end{array}$} & \multirow[t]{2}{*}{$\begin{array}{l}\text { 10CFR20 - } \\
0.1 \text { rem }\end{array}$} & \multicolumn{2}{|c|}{$\begin{array}{c}\text { 10CFR } 50.34- \\
25 \text { rem } \\
\end{array}$} & \multirow[t]{2}{*}{$\begin{array}{l}\text { EPPAGs - } \\
1 \text { rem }\end{array}$} & \multirow[t]{2}{*}{$\begin{array}{c}\text { QHOs - } \\
\text { Individual Risks }\end{array}$} \\
\hline & & $\begin{array}{c}\text { SSC } \\
\text { Performance }\end{array}$ & Site Suitability & & \\
\hline AEs & $\begin{array}{c}\text { Mean } \\
\text { Cumulative @ } \\
\text { EAB }\end{array}$ & & & & $\begin{array}{l}\text { Mean Cumulative } \\
\text { @ } 1 \text { and } 10 \text { miles }\end{array}$ \\
\hline DBEs & & $\begin{array}{l}\text { UpperBound } \\
\text { @EAB }\end{array}$ & $\begin{array}{c}\text { UpperBound @ } \\
\text { EAB }\end{array}$ & $\begin{array}{c}\text { Mean @ } \\
\text { EPZ* }^{*}\end{array}$ & $\begin{array}{l}\text { Mean Cumulative } \\
\text { @ } 1 \text { and } 10 \text { miles }\end{array}$ \\
\hline BDBEs & & & Mean**@EAB & $\begin{array}{c}\text { Mean @ } \\
\text { EPZ* }\end{array}$ & $\begin{array}{l}\text { Mean Cumulative } \\
\text { @ } 1 \text { and } 10 \text { miles }\end{array}$ \\
\hline DBAs & & $\begin{array}{c}\text { Upper Bound } \\
\text { @EAB }\end{array}$ & $\begin{array}{c}\text { UpperBound @ } \\
\text { EAB }\end{array}$ & & \\
\hline
\end{tabular}

*NGNP Design Objective: EPZ = EAB.

**Upper Bound weather per RG 1.145.

\section{REFERENCES}

1. Idaho National Laboratory, "NGNP Fuel Qualification White Paper," INL/EXT-10-17686, Rev. 0, July 2010 (ML102040261).

2. Idaho National Laboratory, "Mechanistic Source Terms White Paper," INL/EXT-10-17997, Rev. 0, July 2010 (ML102040260).

3. Idaho National Laboratory, "NGNP High Temperature Materials White Paper," INL/EXT-09-17187, June 2010 (ML101800221).

4. Idaho National Laboratory, "Next Generation Nuclear Plant Licensing Basis Event Selection White Paper,” INL/EXT-10-19521, September 2010 (ML102630246).

5. Idaho National Laboratory, "Next Generation Nuclear Plant Structures, Systems, and Components Safety Classification White Paper," INL/EXT-10-19509, September 2010 (ML102660144).

6. Idaho National Laboratory, "Next Generation Nuclear Plant Defense-in-Depth Approach," INL/EXT-09-17139, December 2009 (ML093480191).

7. Idaho National Laboratory, "License Structure for Multi-Module Facilities," INL/EXT-10-18178, August 2010 (ML102240273).

8. Idaho National Laboratory, "Modular HTGR Safety Basis and Approach," INL/EXT-11-22708, August 2011 (ML11251A169).

9. Idaho National Laboratory, "Next Generation Nuclear Plant Probabilistic Risk Assessment White Paper," INL/EXT-11-21270, September 2011 (ML11265A082). 
10. Idaho National Laboratory, "Determining the Appropriate Emergency Planning Zone Size and Emergency Planning Attributes for an HTGR," INL/MIS-10-19799, October 2010 (ML103050268).

11. Idaho National Laboratory, "NGNP Nuclear-Industrial Facility and Design Certification Boundaries," INL/EXT-11-21605, July 2011.

12. U.S. Department of Energy, Office of Nuclear Energy, "Next Generation Nuclear Plant Licensing Strategy, A Report to Congress,” August 2008 (ML082330519 and ML082290017).

13. Idaho National Laboratory, "Key Design Requirements for the High Temperature Gas-cooled Reactor Nuclear Heat Supply System,” INL/EXT-10-19887, Rev. 0, September 2010.

14. Idaho National Laboratory, "Next Generation Nuclear Plant System Requirements Manual," INL/EXT-07-12999, Rev. 3, September 2009.

15. Idaho National Laboratory, "End User Functional and Performance Requirements HTGR Energy Supply to Industrial Processes," INL/EXT-10-19808, September 2010.

16. Pacific Northwest National Laboratory, "Engineering Evaluation of X/Q Values Consistent with Regulatory Guide 1.145,” PNNL-19217, February 2010.

17. American Society of Mechanical Engineers (ASME) Boiler \& Pressure Vessel Code, Division III, Rules for Construction of Nuclear Facility Components, Division 5, High Temperature Reactors, November 1, 2011 or later.

18. Idaho National Laboratory, "Scoping Analysis of Source Term and Functional Containment Attenuation Factors," INL/EXT-11-24034, January 2012.

19. Idaho National Laboratory, "COL Application Content Guide for HTGRs: Revision to RG 1.206, Part I - Status Report,” INL/EXT-26895, August 2012.

20. David Petti (INL) letter to U.S. Nuclear Regulatory Commission, Document Control Desk, "Contract No. DE-AC07-05ID14517 - Next Generation Nuclear Plant Submittal - Confirmation of Requested NRC Staff Positions - NRC Project \#0748,” CCN 227793, July 6, 2012. 